\title{
Bandicam: Alternatif Media Pembelajaran Interaktif dan Komunikatif di Masa Pandemi Covid 19
}

\author{
Pirman Ginting ${ }^{1^{*}}$, Yenni Hasnah ${ }^{2}$, Diani Syahputri ${ }^{3}$ \\ 1,2,3 Universitas Muhammadiyah Sumatera Utara, Medan, Indonesia \\ *Corresponding Author: yennihasnah@umsu.ac.id
}

\begin{abstract}
Info Artikel
Diterima: 21/02/2022

Direvisi: 24/02/2022

Disetujui: $25 / 02 / 2022$

Abstract. This activity is Bandicam-based learning media workshop for teacher aims to elevate the competence of teachers in utilizing online learning media in order to create more interesting/interactive/communicative teaching and learning activities, particularly during the Covid 19 pandemic. In an effort to realize this goal, this activity is carried out in collaboration with partner schools through socialization method and workshop. Based on the results, the teachers reveal that this activity was very benefeted for them in enriching the insight and creativity of the teachers to apply more interesting and interactive learning media for online learning so that students would become more motivated and enthusiastic in participating in learning. It is indicated from the ability of teachers to produce learning videos that are quite interesting and communicative through the Bandicam application.
\end{abstract}

Keywords: Bandicam, Learning media, Online learning

\begin{abstract}
Abstrak. Kegiatan ini merupakan workshop media pembelajaran berbasis Bandicam bagi para guru yang bertujuan untuk meningkatkan kompetensi guru dalam memanfaatkan media pembelajaran online guna menciptakan kegiatan belajar mengajar yang lebih menarik/interaktif/komunikatif, khususnya di masa pandemi Covid-19. Dalam upaya mewujudkan tujuan tersebut, kegiatan ini dilaksanakan bekerjasama dengan sekolah mitra melalui metode sosialisasi dan workshop. Berdasarkan hasil evaluasi kegiatan pengabdian, guru mengungkapkan bahwa kegiatan ini sangat bermanfaat bagi mereka dalam memperkaya wawasan dan kreativitas guru untuk menerapkan media pembelajaran yang lebih menarik dan interaktif untuk pembelajaran online sehingga siswa menjadi lebih termotivasi dan antusias dalam mengikuti pembelajaran. Hal ini ditunjukkan dari kemampuan guru dalam menghasilkan video pembelajaran yang cukup menarik dan komunikatif melalui aplikasi Bandicam.
\end{abstract}

Kata Kunci: Bandicam, Media pembelajaran, Pembelajaran online.

How to Cite: Ginting, P., Hasnah, Y., \& Syahputri, D. (2022). Bandicam: Alternatif Media Pembelajaran Interaktif dan Komunikatif di Masa Pandemi Covid 19. Prima Abdika: Jurnal Pengabdian Masyarakat, 2(1), 107-116. https://doi.org/10.37478/abdika.v2i1.1714

(?) Copyright (c) 2022 Pirman Ginting, Yenni Hasnah, Diani Syahputri. This work is licensed under a Creative Commons Attribution-ShareAlike 4.0 International License.

\section{Pendahuluan}

Kemunculan Virus Covid 19 telah membawa banyak perubahan di berbagai sektor kehidupan di berbagai negara. Indonesia, salah satu negara yang juga merasakan dampak dari virus tersebut. Beberapa aspek mengalami perubahan dalam model pelaksanaannya, seperti di bidang pendidikan yang pada awalnya pembelajaran secara umum dilaksanakan secara luring. Namun, pada masa pandemi ini, hal tersebut diselenggarakan melalui daring atau pembelajaran jarak jauh (PJJ). Seperti yang disampaikan oleh Windhiyana (2020) bahwa Dalam bidang pendidikan, model pembelajaran berubah secara drastis karena Covid 19 ; seluruh aktivitas pembelajaran dilaksanakan secara daring mulai dari tingkat sekolah dasar hingga ke perguruan tinggi. Hal yang senada juga dijelaskan oleh Azzahra (2020) bahwa cepatnya proses penyebaran virus corona telah mengganggu proses pelaksanaan pendidikan; sekitar 45 juta siswa terkendala untuk melanjutkan kegiatan belajar mereka di sekolah.

Pelaksanaan pembelajaran secara daring tentunya memiliki kelebihan dan kekurangan mengingat adanya keberagaman di berbagai aspek seperti 
aspek geografis, sosial, ekonomi, dan lainnya. Rosali (2020) mengidentifikasi bahwa ketersediaan kuota internet, jaringan yang tidak stabil, dan alat penunjang seperti gawai dan laptop merupakan bagian dari kendala PJJ. Kemudian Pujiasih (2020) menambahkan bahwa PJJ ini menimbulkan kekurangfahaman siswa terhadap materi pembelajaran. Di sisi lain, Firman \& Rahayu (2020) menyebutkan salah satu kelebihan dari PJJ adalah terciptanya fleksibilitas dan kemandirian dalam belajar serta adanya motivasi untuk lebih aktif dalam belajar. Terlepas dari beberapa sisi positif dan negatif pembelajaran daring, tersebut, PJJ merupakan salah satu alternatif yang ditempuh untuk menekan penyebaran Covid 19. Latip (2020) mengatakan bahwa salah satu bentuk penyesuaian dalam sektor pendidikan selama masa pandemi Covid-19 adalah Pembelajaran Jarak Jauh.

Pembelajaran jarak jauh sangat bergantung keterlaksanaannya pada pemanfaatan teknologi. Melalui teknologi, jarak dan waktu Kemudian dia menambahkan bahwa pemanfaatan teknologi sebagai kunci keberlangsungan PJJ yang dapat menjadi penghubung antara pendidik dan peserta didik. Hal ini juga sejalan dengan apa yang disimpulkan oleh Salsabila, dkk (2020) bahwa teknologi berperan penting dalam pelaksanaan pembelajaran khususnya di masa pandemi Covid 19 ini. Selanjutnya, Sanaky (2015: 231) juga menekankan kebutuhan akan teknologi pembelajaran jarak jauh adalah sebuah kemutlakan dalam proses pembelajaran jarak jauh sehingga pengajar dan pengajar senantiasa menyatu dalam sebuah interaksi pembelajaran. Dengan demikian, para pendidik dituntut untuk melek teknologi sehingga mereka dapat menggunakan teknologi tersebut sebagai media pembelajaran yang efektif.

Terkait media pembelajaran, tidak dapat dipungkiri bahwa hal tersebut merupakan salah satu komponen penting dalam mencapai tujuan pembelajaran yang diharapkan. Tanpa media, pembelajaran tidak akan tercipta dengan baik. Seperti yang dijelaskan oleh Reza (2015) bahwa pembelajaran itu adalah penggunaan media sebagai penghubung antara pendidik dan yang dididik. Wati (2016) juga mengatakan bahwa media pembelajaran digunakan untuk menciptakan komunikasi dan interaksi yang efektif antara pengajar dan pebelajar dalam proses pembelajaran. Oleh karena itu, pelibatan media pembelajaran di masa Covid 19 ini merupakan sebuah keharusan untuk dilakukan.

Media pembelajaran tentunya sangatlah variatif. Namun, pada masa pandemi ini, pemilihan media yang efisien dan efektif adalah sebuah pertimbangan yang besar tanpa mengabaikan terciptanya interaksi belajar yang menarik sehingga tujuan pembelajaran tetap dapat tercapai dengan optimal. Mengingat keberagaman peserta didik dalam sebuah kelas pembelajaran menuntut pendidik untuk mampu menyeleksi media yang tidak hanya monoton pada satu karakteristik pebelajar saja, misalnya hanya media visual atau audio saja tapi alangkah lebih baiknya ada perpaduan keduanya, sehingga kebutuhan anak yang visual dan audio masing-masing dapat tercukupi.

Salah satu media audio visual yang banyak dimanfaatkan pada masa pandemik ini adalah WhatsApp seperti yang dikemukakan oleh Suni (2020) bahwa media yang paling banyak digunakan pada pembelajaran daring adalah WhatsApp. Pernyataan ini juga diperkuat oleh temuan Anugrahana (2020) bahwa 100\% dari guru yang ditelitinya memanfaatkan aplikasi 
WhatsApp sebagai pilihan pertama mereka dalam melaksanakan pembelajaran online.

Begitu juga halnya pada Sekolah Menengah Pertama Bina Satria Mulia, yang dijadikan mitra pada kegiatan pengabdian ini, melalui komunikasi online dengan pimpinan sekolah mengungkapkan bahwa para gurunya juga menjadikan WhatsApp sebagai media utama dalam pembelajaran. Namun, sangat disayangkan bahwa para siswa kebanyakan lebih pasif jika dibandingkan dengan pembelajaran tatap muka seperti biasa di kelas. Kepasifan ini tentunya tidak terlepas dari beberapa kelemahan atau kendala PJJ seperti yang telah diuraikan pada bagian sebelumnya. Secara spesifik, ketidakdinamisan siswa dalam pembelajaran melalui WhatsApp kemungkinan juga dipengaruhi oleh bahan yang di-upload atau dikirim oleh para guru lebih mengarah pada penugasan semata tanpa memberikan pemahaman materi terlebih dahulu secara maksismal. Para siswa dituntut untuk mempelajari materi secara mandiri untuk dapat menyelesaikan tugas-tugas yang diberikan.

Merujuk pada uraian di atas, maka para pendidik diharapkan dapat mengembangkan kompetensinya terkait penggunaan media pembelajaran yang efektif dan efisien khususnya yang relevan dengan situasi pandemi saat ini. Bagaimanapun keterlibatan media pembelajaran diharapkan dapat senantiasa menarik minat dan perhatian belajar peserta didik yang sedikit banyaknya sudah terkuras oleh sistem PJJ di masa Covid 19 karena salah satu sumber motivasinya, pengajar atau temannya tidak dapat berinteraksi langsung dengan mereka seperti biasanya di kelas konvensional. Seperti yang dikemukakan oleh Yunitasari \& Hanifah (2020) bahwa pembelajaran daring pada masa pandemi COVID-19 berdampak pada minat belajar siswa; mereka mengalami kebosanan karena tidak dapat bertemu dengan teman dan gurunya secara langsung. Dengan demikian, PJJ tanpa didukung oleh penggunaan media yang tepat justru dapat menimbulkan kebosanan. Hal ini sebagaimana yang diungkapkan oleh Tafonao (2018) menyampaikan bahwa media dapat berperan untuk mengatasi kebosanan dalam belajar di kelas.

Salah satu media pembelajaran daring yang menarik dan dapat dimaksimalkan penggunaannya adalah Bandicam. Media ini merupakan perpaduan antara visual (gambar) dan audio (suara) dalam bentuk video. Melalui media ini memungkinkan para guru secara maksimal menjelaskan materi pembelajaran sebelum memberikan penugasan sehingga para siswa lebih termotivasi untuk mengikuti pembelajaran walaupun secara online. Media ini juga memberikan kesempatan bagi guru untuk mengkomunikasikan bahan ajar yang disampaikan secara lebih komunikatif/interaktif melalui rekaman kegiatan mengajarnya dalam bentuk video yang dengan mudah dapat di-upload melalui WhatsApp kelompok pembelajaran. Herayanti dkk (2019) menjelaskan Bandicam digunakan dalam melakukan aktivitas rekaman (screen recording) dengan lebih banyak fitur-fitur keren seperti melakukan custom area yang ingin direkam, menggambar sebuah garis atau gambar secara langsung, merekam sambil menampilkan wajah dan lain sebagainya. Di kesempatan lain, Cahyono (2021) menyimpulkan bahwa Bandicam dapat membuat kemampuan untuk mengabstraksi materi pembelajaran lebih baik. Selanjutnya, Herayanti \& Syafitri (2019) juga mengambil kesimpulan yang serupa, yakni media audio visual berbasis Bandicam terbukti dalam menciptakan pembelajaran yang efektif. 
Berdasarkan analisis situasi di atas, maka teridentifikasi beberapa masalah terkait dengan pemahaman guru tentang media pembelajaran: (1) adanya perubahan model pembelajaran dari luring menjadi daring karena situasi pandemi Covid 19, (2) pendidik dan peserta didik belum terbiasa dalam melakukan PJJ sehingga pelaksanaannya belum maksimal, (3) kompetensi pendidik dalam memanfaatkan media pembelajaran online belum memadai, (4) media pembelajaran daring yang digunakan belum bervariasi; masih terfokus pada satu media, yakni WhatsApp, (5) penggunaan media pembelajaran tertentu masih mengalami hambatan sehingga tidak dapat dioperasikan secara optimal, dan (6) bahan ajar yang di-upload kepada peserta didik masih kurang menarik sehingga memunculkan kejenuhan dalam belajar.

Serangkaian permasalahan di atas adalah permasalahan yang harus segera diatasi sehingga pembelajaran dapat berlangsung lebih efektif walaupun dimasa pandemi Covid 19 dengam model pembelajaran daring. Melalui kegiatan PKM ini para guru SMP Bina Satria Mulia dibekali dengan kompetensi pemanfaatan media online, khususnya video pembelajaran berbasis Bandicam dalam rangka menciptakan pembelajaran yang lebih menarik sehingga peserta didik lebih termotivasi dalam belajar walaupun secara daring.

\section{Metode Pelaksanaan}

Kegiatan PKM diperuntukkan bagi para guru di Yayasan Pendidikan Bina Satria Mulia Medan yang berjumlah 15 orang sebagai peserta aktif kegiatan. Kegiatan dilaksanakan melalui metode sosialisasi dan workshop yang meliputi tahapan persiapan, pelaksanaan, dan penutup serta evaluasi. Pada tahap awal, kegiatan yang dilakukan mencakup persiapan administrasi, lokasi dan sarana prasarana untuk keperluan pelaksanaan kegiatan. Selanjutnya adalah tahap pelaksanaan dimana kegiatan sosialisasi materi, pelatihan dan pendampingan diberikan kepada peserta kegiatan. Pada akhir pelaksananan pelatihan diambil respon/feedback dari peserta terkait pelaksanaan program sebagai bahan evaluasi. pada tahap akhir kegiatan yakni tahap penutupan dan evaluasi dilakukan evaluasi terhadap pelaksanaan kegiatan dan penyusunan laporan akhir kegiatan.

Untuk mencapai tujuan yang diharapkan dalam pelaksanaan kegiatan PKM ini, maka metode pendekatan yang dilaksanakan meliputi (a) ceramah, diskusi, dan tanya jawab, (b) pelatihan, (c) pendampingan, dan (d) Evaluasi.

Metode ceramah digunakan dalam menyampaikan materi pelatihan kepada peserta kegiatan PKM terkait konsep dasar media pembelajaran, khususnya media video berbasis Bandicam. Setelah sosialisasi dan pemantapan materi pelatihan, para peserta langsung praktek membuat media pembelajaran yang dimaksud baik secara berkelompok maupun individu. Pendampingan secara bersamaan diberikan kepada peserta pada saat mereka melaksanakan praktek pembuatan media pembelajaran. Pendampingan ini lebih difokuskan pada peserta yang masih merasa sulit atau kebingungan.

Proses evaluasi dilaksanakan oleh tim pelaksana terhadap pelaksanaan kegiatan-kegiatan yang ada dalam program pengabdian. Pada saat ceramah, tanya jawab, dan diskusi, tim pelaksanan mengevaluasi pemahaman peserta atas materi yang disampaikan oleh tim pelaksana. Dalam kegiatan evaluasi pemahaman tentang media pembelajaran, tim pelaksana mengevaluasi 
peserta yang berpartisipasi dalam kegiatan ini terkait sejauh mana para guru mampu memanfaatkan media online yang dimaksud.

\section{Hasil dan Pembahasan}

Pada bagian ini diuraikan terkait hasil dari kegiatan PKM beserta pembahasannya. Sebelum penyajian dan penjelasan data sebagai hasil dari kegiatan tersebut, maka pada bagian awal disampaikan terlebih dahulu mengenai uaraian pelaksanaan kegiatan yang telah dilakukan sebagai berikut.

\section{Pelaksanaan Kegiatan PKM}

Pelaksanaan kegiatan PKM mendapatkan dukungan yang sangat baik dari pihak mitra. Kesediaan mitra untuk menyiapkan peserta dan sarana tertentu sangat berkontribusi dalam menunjang keterlaksanaan kegiatan PKM. Kemudian, sikap positif dari para guru selaku peserta kegiatan juga ditunjukkan dalam bentuk semangat dan antusiasme yang tinggi melalui peran aktif mereka selama pelaksanaan kegiatan, mulai dari acara pembukaan hingga penutupan.

Pada tahap pembukaan, serangkaian kegiatan yang dilaksanakan berupa kata pembukaan dari moderator. Kemudian, kata sambutan oleh ketua pelaksana kegiatan PKM yang dalam sambutannya menyampaikan ucapan terima kasih kepada sekolah atas kesediaannya sebagai mitra dan partisipasi yang luar biasa, baik dalam penyiapan peserta kegiatan maupun tempat pelaksanaan kegiatan. Dia juga menyampaikan harapannya bahwa silaturrahim dengan sekolah dapat terus berlanjut di masa mendatang yang salah satu bentuknya melalui pelaksanaan kegiatan PKM. Dia mengakhiri sambutannya dengan kembali mengucapkan rasa syukur dan terima kasihnya kepada semua pihak yang telah membantu dalam menyukseskan pelaksanaan kegiatan PKM ini. Selanjutnya, kata sambutan juga disampaikan oleh pihak sekolah sebagai mitra kegiatan ini dan sekaligus membuka pelaksanaan kegiatan. Pihak mitra juga berterima kasih atas kegiatan PKM ini dan mengatakan bahwa kesempatan menjadi mitra PKM merupakan sebuah kebanggaan yang luar biasa karena melalui kegiatan ini mereka dapat saling berbagi atau berdiskusi berbagai hal, khususnya yang berdampak terhadap peningkatan kualitas pendidikan di sekolah. Di penghujung sambutannya, pihak sekolah juga memiliki harapan semoga kegiatan serupa dapat kembali dilaksanakan di sekolah tersebut.

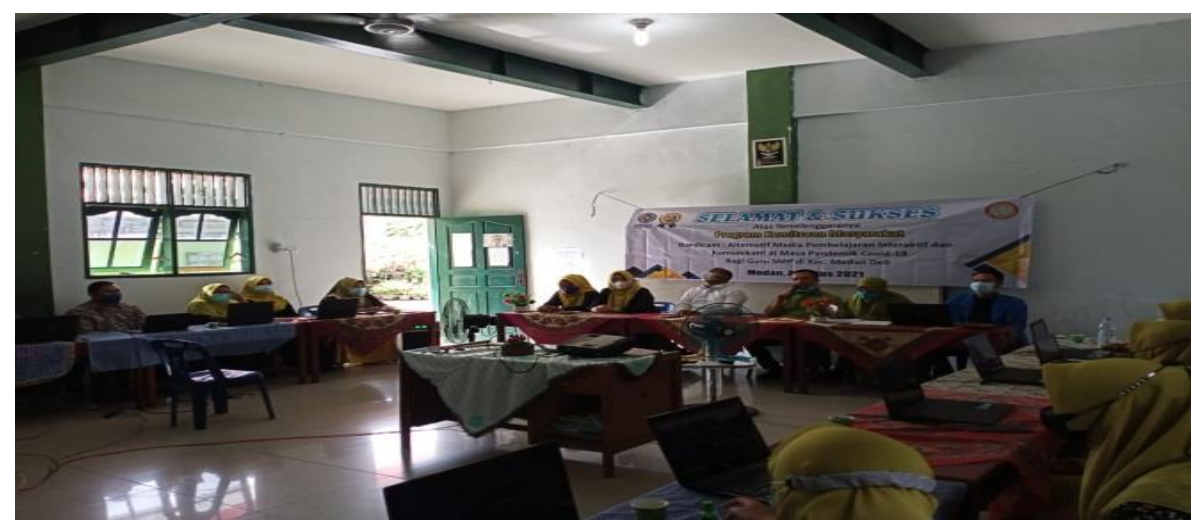

Gambar 1. Acara pembukaan kegiatan pkm 
Setelah rangkaian acara pembukaan selesai, acara inti (penyajian materi diskusi/sharing, kerja kelompok, pembimbingan/pendampingan peserta, dan evaluasi kelompok) dilakukan secara bertahap. Pada tahapan ini, kegiatan diawali dengan pemaparan materi terkait media pembelajaran berbasis Bandicam oleh tim dosen pelaksana PKM. Secara ringkas, materi mencakup konsep dasar aplikasi Bandicam, langkah-langkah pengoperasian Bandicam, dan praktek menggunakan Bandicam. Penyajian materi cukup runtut, menarik dan interaktif yang didukung oleh penggunaan media power point sehingga para peserta dapat memahami materi dengan baik.

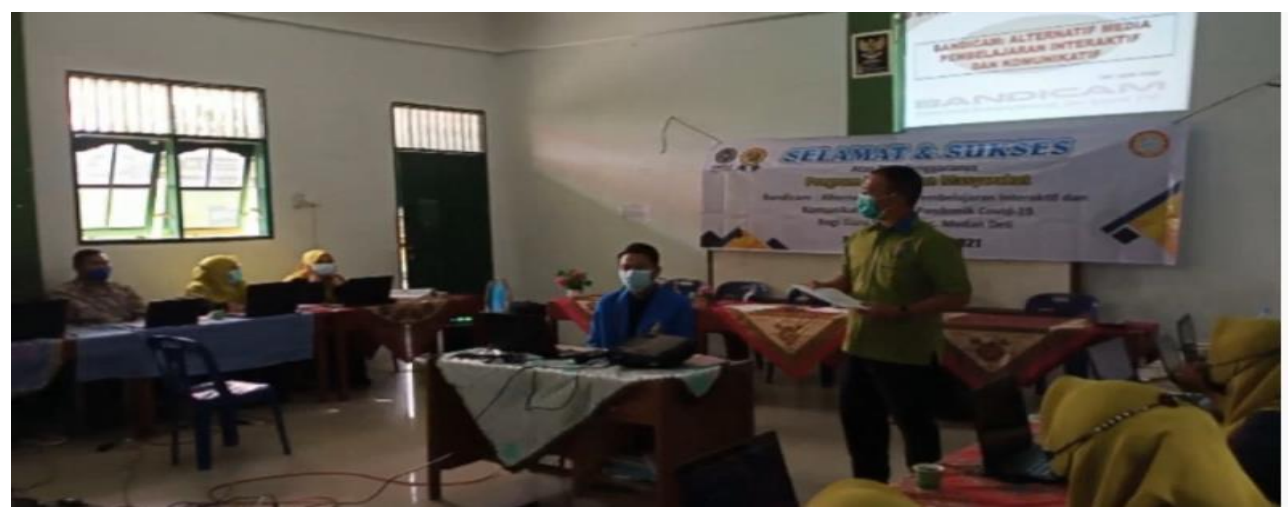

Gambar 2. Penyampaian materi oleh tim pelaksana $\mathrm{pkm}$

Kegiatan berikutnya dilanjutkan dengan sesi diskusi/sharing antara pemateri dan peserta. Dalam sesi ini, ada beberapa pertanyaan yang disampaikan oleh para peserta dan langsung direspon oleh pemateri dengan memberikan penjelasan yang memadai sehingga para peserta memperoleh pemahaman yang lebih mendalam, khususnya dalam pengoperasian aplikasi Bandicam.

Setelah peserta kegiatan memahami konsep Bandicam, kegiatan dilanjutkan dengan praktek menggunakannya. Dalam prakteknya, tim pelaksana melakukan pendampingan untuk memfasilitasi kendala atau kesulitan peserta dalam menyusun dan menganalisis soal tersebut.

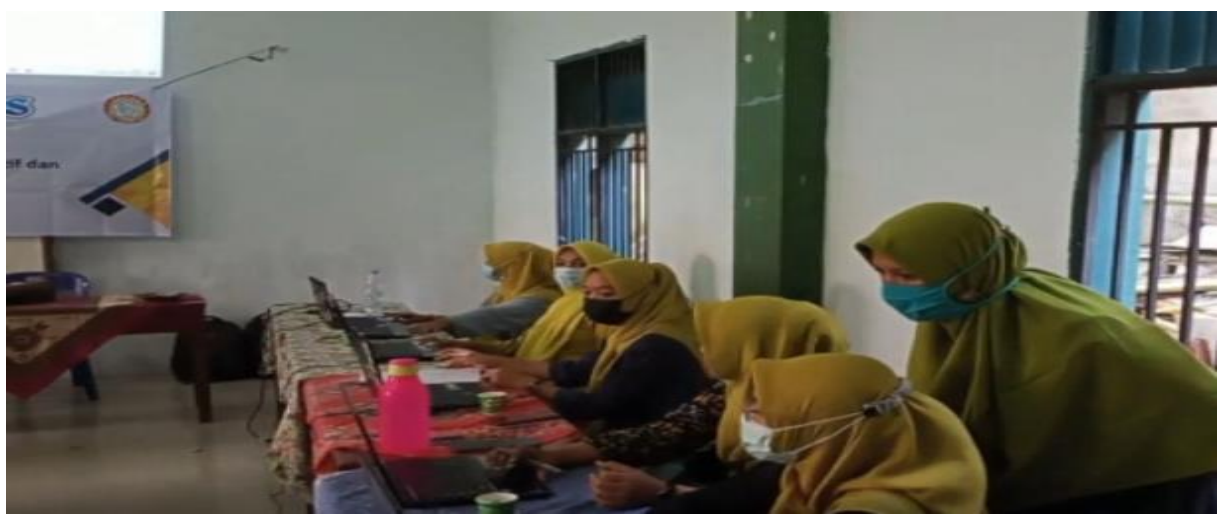

Gambar 3. Kegiatan pendampingan oleh tim Ppelaksana

Pada akhir kegiatan, tim PKM melakukan evaluasi terkait pelaksanaan kegiatan dengan bertanya langsung kepada para peserta terkait respon 
mereka terhadap penggunaan aplikasi Bandicam sebagai media pembeajaran jarak jauh daring), khususnya di masa pandemi Covid 19 ini.

\section{Evaluasi Hasil Kegiatan PKM}

Proses evaluasi yang dilakukan pada kegiatan PKM ini merujuk pada hasil kerja peserta berupa video pembelajaran berbasis Bandicam. Video tersebut tentunya sangat efektif dimanfaatkan terutama untuk sistem pembelajaran online di masa pandemi Covid 19. Kisa dan Stein (2017) mengidentifikasikan bahwa video pembelajaran sebagai produk pembelajaran mempunyai manfaat berkelanjutan dan dapat dimanfaatkan untuk menjangkau semua komponen yang memerlukan dan memberikan dampak positif bagi peserta didik. Kemudian, berdasarkan hasil kerja peserta kegiatan terlihat bahwa adanya peningkatan kamampuan para guru, baik secara teoritis maupun praktis terkait penggunaan media pembelajaran berbasis Bandicam.

Kegiatan pengabdian ini sangat memberikan manfaat bagi para guru di sekolah mitra dalam hal menggunakan media pembelajaran yang lebih menarik, khususnya untuk pembelajaran secara daring. Melalui kegiatan ini, para guru telah mampu membuat video pembelajaran yang cukup menarik dan komunikatif melalui aplikasi Bandicam. Penggunaan Bandicam ini dipersepsikan guru sebagai media pembelajaran yang lebih menarik dan komunikatif serta efisien. Keefisiensiannya terletak pada muatan video yang dihasilkan lebih minim namun tampilan videonya jelas dan bersih. Terkait hal ini, Kristiawan et.al (2021) menegaskan bahwa media video seperti bandicam dan sebagainya mempunyai kemampuan yang lebih baik. Para guru juga mengasumsikan bahwa dengan tampian video seperti itu, para siswa mereka tentunya lebih bersemangat menyaksikan penjelasan yang disampaikan oleh guru. Para guru juga menyampaikan bahwa melalui video tersebut memungkinkan siswa untuk lebih fleksibel dalam mengikuti pembelajaran, karena dapat diakses kapan dan dimana saja. Serangkaianan asumsi para guru ini tentunya mengarah pada akan terciptanya pembelajaran jarak jauh yang lebih optimal dan efektif melalui pemanfaatan aplikasi Bandicam. Seperti yang disimpulkan oleh Kristiawan et.al (2021) bahwa Bandicam menjadikan pembelajaran daring optimal, efektif dan dapat meningkatkan motivasi peserta didik. Selanjutnya, Herayanti \& Syafitri (2019) juga membuktikan bahwa melalui Bandicam dapat tercipta pembelajaran yang efektif.

Kesuksesan pelaksanaan kegiatan sangat dipengaruhi oleh dukungan dari pihak mitra. Pelatihan mendapatkan dukungan penuh dari pihak mitra yang melalui ketua yayasan menyambut dan mengapresiasi baik kegiatan ini dan menyatakan kesediaan sebagai mitra untuk program-program PKM selanjutnya. Selanjutnya, faktor pendukung juga terlihat dari kesediaan mitra, yakni para guru untuk berpartisipasi langsung dalam kegiatan sebagai peserta dan penyediakan fasilitas-fasilitas tertentu yang mendukung pelaksanaan kegiatan seperti ruangan, meja, kursi, proyektor, dan lain sebagainya. Kegiatan ini juga mendapat respon positif dari para guru selaku peserta kegiatan, yang ditunjukkan dari peran aktif mereka selama proses kegiatan berlangsung. Para peserta sangat antuasias dalam melakukan praktek pembuatan video pembelajaran melalui Bandicam. 
Pada saat pelaksanaan kegiatan pelatihan media pembelajaran, tim pelaksana telah menyampaikan kepada para peserta bahwa kegiatan tersebut bukan hanya berakhir ketika pelaksanaannya selesai dilakukan. Namun, hal yang terpenting adalah setelah selesainya kegiatan tersebut, para peserta kegiatan diharapkan senantiasa mengimplementasikannya dalam proses pembelajaran demi peningkatan mutu pembelajaran. Oleh karena itu, tim pelaksana kegiatan pengabdian senantiasa melakukan evaluasi terkait ada atau tidaknya keberlanjutan kegiatan yang telah dilaksanakan dengan melakukan komunikasi lanjutan dengan pihak mitra.

\section{Kendala yang Dihadapi}

Pelaksanaan kegiatan ini juga tidak terlepas dari beberapa hambatan/kendala. Salah satu hambatan dari keberlanjutan kegiatan ini adalah kesediaan para guru untuk senantiasa mau menciptakan pembelajaran yang lebih menarik melalui pemanfaatan media Bandicam. Yang menjadi sedikit kekhawatirkan adalah hanya sebagian guru saja yang siap berkorban waktu, tenaga, bahkan finansial untuk menyiapkan bahan pembelajaran berbasis Bandicam. Oleh karena itu, sangat diperlukan komitmen dari para guru untuk senantiasa melakukan upaya-upaya peningkatan kualitas pendidikan yang salah satunya adalah melalui pamanfaatan media pembelajaran yang lebih menarik. Dalam hal ini, pemegang kebijakan di sekolah sangat dibutuhkan andilnya untuk senantiasa mendukung para tenaga pengajarnya untuk terus berbenah dalam melaksanakan kegiatan pembelajaran yang lebih baik dari sebelumnya. Karena bagaimanapun penyiapan pembelajaran yang baik membutuhkan banyak pengorbanan, baik dari segi waktu, tenaga, bahkan dana.

Selain hambatan di atas, ketidakterbiasaan melaksanakan pembelajaran berbasis Bandicam sangat menuntut kesabaran dan kreatifitas pendidik sehingga dapat membelajarkan siswa semaksimal mungkin. Di sisi lain, penggunaan media Bandicam yang secara spesifik sangat mendukung sistem pembelajaran online juga memberatkan sebagian besar guru/siswa karena harus menyiapkan paket internet yang memadai untuk dapat memberikan/menerima pembelajaran.

\section{Simpulan dan Tindak Lanjut}

Bagian ini adalah bagian yang berisi tentang kesimpulan dan saran. Kesimpulan akan menjadi jawaban dari capaian dan/atau tujuan yang telah dipaparkan pada bagian pendahuluan. Kesimpulan tidak boleh hanya berisi pengulangan hasil dan pembahasan. Harus menjadi ringkasan hasil seperti yang diharapkan penulis dalam tujuan. Saran berisi tentang rencana-rencana lanjutan yang terkait dengan ide-ide penulis, disajikan dalam bentuk paragraf.

Berdasarkan hasil kegiatan dapat disimpulkan bahwa pelaksanaan kegiatan pengabdian ini dapat terlaksana dengan baik, lancar dan sesuai dengan yang direncanakan karena adanya respon dan dukungan yang baik dari pihak mitra. Dalam hal ini, para peserta sangat antusias dalam mengikuti kegiatan pelatihan. Hal ini terlihat dari partisipasi setiap peserta dalam mengikuti kegiatan mulai dari awal sampai akhir kegiatan. Partisipasi yang sangat baik juga ditunjukkan oleh peserta pelatihan melalui pengerjaan tugas pelatihan yang diberikan. Dalam hal ini, setiap peserta membuat karyanya dalam bentuk video pembelajaran berbasis Bandicam. 
Melalui kegiatan PKM ini, tim pelaksana PKM memberikan saran khususnya kepada para guru sebagai peserta kegiatan untuk senantiasa melakukan inovasi dalam pelaksanaan pembelajaran yang salah satunya adalah melalui pemanfaatan media pembelajaran yang lebih menarik sehingga para siswa dapat lebih termotivasi dan bersemangat dalam mengikuti pembeajaran yang disampaikan. Oleh karena itu, diperlukan komitmen dari sekolah mitra untuk senantiasa berkreasi dan berinovatif dalam pelaksanaan sebagai salah satu upaya untuk meningkatan kualitas pembelajaran.

\section{Ucapan Terimakasih}

Tim penulis mengucapkan terima kasih kepada Lembaga Pengabdian Pada Masyarakat (LPPM) Universitas Muhammadiyah Sumatera Utara yang telah mendanai kegiatan pengabdian ini sehingga dapat terlaksana dengan baik dan lancar.

\section{Daftar Pustaka}

Anugrahana, A. (2020). Hambatan, Solusi dan Harapan: Pembelajaran Daring Selama Masa Pandemi Covid-19 Oleh Guru Sekolah Dasar. Scholaria: Jurnal Pendidikan Dan Kebudayaan, 10(3), 282-289. https: / /doi.org/ 10.24246/j.js.2020.v10.i3.p282-289

Azzahra, N. F. (2020). Mengkaji Hambatan Pembelajaran Jarak Jauh di Indonesia di Masa Pandemi Covid-19. Center for Indonesians Policy Studies, 19(2), 1-9.

Cahyono, H. (2021). Penggunaan Video Pembelajaran Berbasis Aplikasi Bandicam pada Mata Kuliah Teori Graf Untuk Meningkatkan Kemampuan Abstraksi Mahasiswa. Jurnal Pendidikan Modern, 6(2), 114119. https://doi.org/10.37471/jpm.v6i2.205

Firman, F., \& Rahayu, S. (2020). Pembelajaran Online di Tengah Pandemi Covid-19. Indonesian Journal of Educational Science (IJES), 2(2), 81-89. https://doi.org/10.31605/ijes.v2i2.659.

Hanifah S. U., Irna Sari, L., Haibati Lathif, K., Puji Lestari, A., \& Ayuning, A. (2020). Peran Teknologi dalam Pembelajaran di Masa Pandemi Covid-19. Al-Mutharahah: Jurnal Penelitian Dan Kajian Sosial Keagamaan, 17(2), 188-198. https://doi.org/10.46781/al-mutharahah.v17i2.138.

Herayanti, L., \& Safitri, B. R. A. (2019). Pembelajaran Mendesain Rumah Menggunakan Media Audio Visual Dengan Memanfaatkan Bandicam. Jurnal Pendidikan Fisika Dan Teknologi, 5(2), 305-309. https: / / doi.org/ 10.29303/jpft.v5i2.1429

Herayanti, L., Safitri, B., Sukroyanti, B., \& Putrayadi, W. (2019). Pelatihan Pembuatan Video Pembelajaran bagi Guru-Guru di SDN 1 Ubung dengan Memanfaatkan Bandicam. Jurnal Pendidikan Dan Pengabdian Masyarakat, 2(4), 1689-1699.

Kristiawan, M., Aminudin, N., \& Rizki, F. (2021). Optimalisasi Pembelajaran Daring Berbasis Aplikasi Online bagi Calon Guru Pendidikan Anak Usia Dini. Jurnal Obsesi: Jurnal Pendidikan Anak Usia Dini, 5(2), 1905-1914. DOI: $10.31004 /$ obsesi.v5i2.942

Kisa, T.M., \& Stein, K.M. (2017). Designing, Facilitating, and Scaling-Up Video-Based Professional Development: Supporting Complex Forms of 
Teaching in Science and Mathematics. International Journal of STEM Education, 4(1), 1-9. https: / /www.ncbi.nlm.nih.gov/pmc/articles/PMC6310378/

Latip, A. (2020). Peran Literasi Teknologi Informasi dan Komunikasi pada Pembelajaran Jarak Jauh di Masa Pandemi Covid-19. EduTeach: Jurnal Edukasi Dan Teknologi Pembelajaran, 1(2), 108-116. https://doi.org/10.37859/eduteach.v1i2.1956

Pujiasih, E. (2020). Membangun Generasi Emas dengan Variasi Pembelajaran Online di Masa Pandemi Covid-19. Ideguru: Jurnal Karya Ilmiah Guru, 5(1), 42-48. https: / / doi.org/10.51169/ideguru.v5i1.136

Reza. (2015). Pengertian Media Pembelajaran. Media Pembelajaran, 4(1), 1232.

Rosali, E. S. (2020). Aktifitas Pembelajaran Daring pada Masa Pandemi Covid -19. Geography Science Education Journal (GEOSEE), 1(1), 21-30.

Sanaky, H. AH. (2015). Media Pembelajaran Interaktif-Inovatif. Yogyakarta: Kaukaba Dipantara.

Suni Astini N. K. (2020). Tantangan dan Peluang Pemanfaatan Teknologi Informasi dalam Pembelajaran Online Masa Covid-19. Cetta: Jurnal Ilmu Pendidikan, 3(2), 241-255. https://doi.org/10.37329/cetta.v3i2.452

Tafonao, T. (2018). Peranan Media Pembelajaran dalam Meningkatkan Minat Belajar Mahasiswa. Jurnal Komunikasi Pendidikan, 2(2), 103-114. https://doi.org/10.32585/jkp.v2i2.113

Wati, E. R. (2016). Ragam Media Pembelajaran. Yogyakarta: Kata Pena.

Windhiyana, E. (2020). Dampak Covid-19 terhadap Kegiatan Pembelajaran Online di Perguruan Tinggi Kristen di Indonesia. Perspektif Ilmu Pendidikan, 34(1), 1-8. https://doi.org/10.21009/pip.341.1

Yunitasari, R., \& Hanifah, U. (2020). Pengaruh Pembelajaran Daring terhadap Minat Belajar Siswa pada Masa COVID 19. Edukatif: Jurnal Ilmu Pendidikan, 2(3), 236-240. 